\title{
Grażyna Gajewska
}

Adam Mickiewicz University

e-mail: gajewska@amu.edu.pl

\section{ECOLOGY AND SCIENCE FICTION. MANAGING IMAGINATION IN THE AGE OF THE ANTHROPOCENE}

\begin{abstract}
When formulating proecological strategies, social imagination is devoted relatively little attention. Contribution of the humanities to the management in the age of the Anthropocene is most often perceived as explaining threats that we and the future human and non-human beings will have to face as a result of irresponsible environmental policies. Hence, the presumed task of the humanities (and social science) consists primarily in analyzing and presenting the causes and the processes which culminated in the climate crisis and the decline of biodiversity. However, such an approach does not allow this knowledge to be actively engaged in constructing alternative, proecological attitudes. Consequently, I argue in this paper that in order for the state of affairs to change one requires not only new scientific tools (methodology, language), but also new sensitivity and aesthetics.

The author argues that the challenges of the current times, resulting from environmental change, destruction of habitats and ecological disasters, direct our sensibilities and aesthetics ever more tangibly towards the fantastic: horror, science fiction, or fantasy. However, while ecohorror mainly exposes the negative aftermath of the Anthropocene - culminating in the inevitable disaster - science fiction offers leeway for a more speculative approach, enabling one to construct such visions of reality in which multispecies justice will be observed and cultivated. It is therefore suggested that there is much need for a science fiction aesthetic and narration that would be capable of guiding us out of the anthropocentric entanglement and the Anthropocene into the Chthulucene (as conceived by Haraway).
\end{abstract}

Keywords: science fiction, fantasy, ecohorror, Anthropocene/Capitalocene, social imagination 
Science fiction is the realism of our time. Kim Stanley Robinson, Coronavirus Is Rewriting Our Imaginations

\section{Introduction - managing imagination in the age of the Anthropocene/Capitalocene}

During one of the 2019 seminars with students of the Institute of Film, Media, and Audiovisual Arts $^{1}$ a female student admitted that the disquieting reports concerning climate change and the associated social consequences cause her and a circle of her peers to fear starting a family. It followed from the conversation that the most acute anxiety is engendered by the envisioned inability to ensure such conditions for the future generations that they may live a healthy and safe lives in the age of advanced Anthropocene. Similar sentiments were expressed by the young people gathered inside and in front of the Palace of Culture in Warsaw during the Congress of Women, whose eleventh edition in 2019 was held under the catchphrase Equality, Ecology, Democracy. Although the forecasts presented at the congress by experts and ecological activists suggest that the alarm should be sounded very loudly indeed, one felt optimistic about the fact that so many people want to listen, talk, and act to change the state of affairs (whether as individuals, a community, or institution). It would seem that the public imagination grows increasingly aware of the need for change, not only where individual lifestyles are concerned but also (or perhaps above all) in the sphere of expectations with regard to political strategies and party platforms. In order to overcome or at least mitigate the destructive environmental impact of human actions attempts are made - with varying success - to mobilize the political and the business world, and develop strategies for sustainable development and ecological responsibility of enterprises. Management thus understood would ideally lead to environmental justice encompassing multiple species.

When formulating proecological strategies, social imagination is devoted relatively little attention. Contribution of the humanities to the management in the age of the Anthropocene is most often perceived as explaining threats that we and the future human and non-human beings will have to face as a result of irresponsible environmental policies. Hence, the presumed task of the humanities (and social science) consists primarily in analyzing and presenting the causes and the processes which culminated in the climate crisis and the decline of biodiversity. However, such an approach does not allow this knowledge to be actively engaged in constructing alternative, proecological attitudes. Consequently, I argue in this paper that in order for the state of affairs to change one requires not only new scientific tools (methodology, language),

BA seminar in the academic year 2019/2020, entitled Science fiction literature and film: Visions of the future and/or alternative world. 
but also new sensitivity and aesthetics. Thus, the management of imagination referred to in the title would mean constructing a novel model of cognition at epistemological, ontological, axiological, and aesthetic levels. It also means searching for such types, genres, and genre varieties of cultural texts - in literature, film, theatre, computer games, or visual arts - which most clearly and vividly convey diverse scenarios of human - non-human justice (or injustice). The second proposition advanced here states that at present it is the genre of the fantastic which carries the greatest potential in terms of ecology. Naturally, one has to take the various "hues" of the fantastic into account, including horror, science fiction, and fantasy. ${ }^{2}$ More specifically, it is argued that particular attention should be paid to speculative science fiction which explores the themes of ecology and multispecies justice. This current within the fantastic seeks to unfold alternative pictures of reality, thus provoking the readers to rethink the place of people on Earth and reconsider our relationships with non-humans and political-ethical-aesthetic responsibility for possible (or probable) shapes of the future. At the same time those speculations - as products of their times - reveal the contemporary notions of sci-fi authors and readers concerning the possible, probable, or anticipated direction we may follow to transcend anthropocentric, phallogocentric $^{3}$ thinking and orient our attention, sensibility and aesthetics towards biodiversity.

For these reasons, science fiction occupies a prominent place in ecocritism, construed as a current in literature studies which examines the natural world as it is represented in literary texts. As Cheryll Glotfelty explains:

Ecocriticism takes as its subjects the interconnections between nature and culture, specifically the cultural artifacts of language and literature. As a critical stance, it has one foot in literature and the other on land; as a theoretical discourse, it negotiates between the human and the nonhuman. ${ }^{4}$

Just as ecocriticism cannot be claimed to be an exceptionally innovative approach in the field of literature studies, ${ }^{5}$ combining it with the analysis of alternative or fu-

2 In American and English literary studies 'science fiction' is consistently defined as a genre, while in Polish literary studies sci-fi is rather defined as a genre variety. In this article, I assume that fantastic literature is a genre and that science fiction, fantasy, and horror are varieties of fantastic literature. See: G. Gazda (ed.), Słownik rodzajów i gatunków literackich, Wydawnictwo Naukowe PWN, Warszawa 2019, 2nd edition, term: science fiction, pp. 998-1001.

3 In the series of essays entitled L'animal que donc je suis, Jacques Derrida that we have not yet worked through the trauma of Darwin's theory of evolution. According to the French philosopher, the trau$\mathrm{ma}$ is at the root of the logocentrism/phallogocentrism which manifests - among other things - in the conviction of human superiority over animals. J. Derrida, The Animal That Therefore I Am, ed. M.L. Mallet, transl. D. Wills, Fordham University Press, New York 2008, p. 136.

4 C. Glotfelty, Introduction: Literary Studies in an Age of Environmental Crisis [in:] C. Glotfelty, H. Fromm (eds.), The Ecocriticism Reader: Landmarks in Literary Ecology, University of the Georgia Press, Athens-London 1996, p. XIX.

5 On the changes of the thematic and methodological scope of ecocriticism in past decades see T. Clark, The Cambridge Introduction to Literature and the Environment, Cambridge University Press, Cambridge 2011; G. Garrard, Ecocriticism, Routledge, New York 2012; G. Garrard (ed.), The Oxford Handbook of Ecocriticism, Oxford University Press, New York 2014. 
turistic realities depicted in science fiction is not a novel trend either. For instance, it was already over two decades ago that Ursula K. Heise, wrote in her letter to the participants of the Forum on Literatures of the Environment:

$[\mathrm{O}]$ ne of the contemporary genres in which questions about nature and environmental issues emerge most clearly is science fiction: from the novels and short stories of Brian Aldiss, John Brunner, and Ursula K. Le Guin in the 1960s and 1970s to those of Carl Amery, David Brin, Kim Stanley Robinson, and Scott Russell Sanders in the 1980s and 1990s, science fiction is one of the genres that have most persistently and most daringly engaged environmental questions and their challenge to our vision of the future. ${ }^{6}$

The issue was articulated in more specific terms by Patrick D. Murphy, who observed that analysis of environmentally-oriented science fiction literature may yield much information about the imagined relationships between humans with non-human life forms, as well as reveals ecological extrapolations of the conflict and crisis based on what has been envisioned. ${ }^{7}$ Murphy is not alone in his argumentation. The advantages of science fiction - or the fantastic in the broader sense - as a genre which offers a conduit for the anxieties, hopes and speculative visions of "improving the world" and halting the detrimental human impact on the environment has been discussed by such researchers as Ali Sperling, ${ }^{8}$ Gerry Canavan, ${ }^{9}$ Rebecca Evans, ${ }^{10}$ Adeline Johns-Putra, ${ }^{11}$ Eric C. Otto, ${ }^{12}$ Amitav Ghosh, ${ }^{13}$ and Pramod K. Nayar. ${ }^{14}$

6 Quoted from the letter by U.K. Heise sent to the Forum on Literatures of the Environment in 1999. After: E. Otto, Science Fiction and the Ecological Conscience, University of Florida, 2006, p. 15. Doctoral dissertation published online: http://etd.fcla.edu/UF/UFE0013481/otto_e.pdf (accessed: 2.03.2021).

7 Ibidem.

8 A. Sperling, Climate Fictions, "Paradoxa: Studies in World Literary Genres" 2019-2020, no. 31, pp. 1-17; Radiating Exposures [in:] C. Holzhey, A. Wedemeyer (eds.), Weathering: Ecologies of Exposure, ICI Berlin Press, Berlin 2020, pp. 41-62; Queer Ingestions: Weird, Vegetative Bodies in Jeff VanderMeer's Fiction [in:] K.E. Bishop, D. Higgins, J. Määtä (eds.), Plants in Science Fiction: Speculative Vegetation, University of Wales Press, Cardiff 2020; Second Skins: A Body Ecology of Sickness in 'The Southern Reach Trilogy', "Paradoxa: Studies in World Literary Genres" 2016, no. 28, pp. 231-255.

9 G. Canavan, K.S. Robinson (eds.), Green Planets: Ecology and Science Fictions, Wesleyan University Press, Middletown 2014.

10 R. Evans, Nomenclature, Narrative, and Novum: 'The Anthropocene' and/as Science Fiction, "Science Fiction Studies" 2018, no. 45, pp. 484-499; eadem, Fantastic Futures? Cli-fi, Climate Justice, and Queer Futurity, "Resilience: A Journal of the Environmental Humanities" 2017, vol. 4, no. 2-3, pp. 94-110.

11 A. Johns-Putra (ed.), Climate and Literature, Cambridge University Press, Cambridge-New YorkMelbourne-New Delhi 2019.

12 E.C. Otto, Green Speculations: Science Fiction and Transformative Environmentalism, The Ohio State University Press, Columbus 2012.

13 A. Ghosh, The Great Derangement: Climate Change and the Unthinkable, The University of Chicago Press, Chicago-London 2016.

14 P.K. Nayar, Posthumanism, Polity Press, Cambridge 2014. 
Despite certain differences of themes and methodologies employed in their inquiry, all researchers underline that literary (and filmic) representations of nature are not only generated by particular cultures, but also play an important role in creating such cultures. Thus, if we want to understand our contemporary attitude towards the environment, science fiction literature and film may provide a splendid point of departure.

\section{The fantastic in the ecocritical discussion}

Ecocriticism studies the images of nature and human approaches to non-human life forms in various literary genres from distinct historical periods and cultural areas, employing a range of methodologies for that purpose. The fantastic is given a particular place in those discussions, as both in public debates and in critical texts one engages "thinking with the fantastic", making reference to the plots, motifs, and protagonists from horror, science fiction, and fantasy. Predominantly, the references draw on the pessimistic scenarios presented in the so-called dark science fiction and horrors. This is hardly surprising, considering that the problems and issues of the Anthropocene are brought to the fore in those very modalities of the fantastic. The preface to In the Dust of This Planet: Horror of Philosophy states as follows:

The world is increasingly unthinkable - a world of planetary disasters, emerging pandemics, tectonic shifts, strange weather, oil-drenched seascapes, and the furtive, always-looming threat of extinction. In spite of our daily concerns, wants, and desires, it is increasingly difficult to comprehend the world in which we live and of which we are a part. To confront this idea is to confront an absolute limit to our ability to adequately understand the world at all - an idea that has been a central motif of the horror genre for some time. ${ }^{15}$

The themes and the tasks of that variety of the fantastic are formulated in slightly different terms by the author of the entry for 'ecohorror' in the 2018 Posthuman Glossary:

Ecohorror reflects our fears about non-human nature in a variety of ways. Perhaps animals will attack us, perhaps we will lose our place at the top of the animal hierarchy, or perhaps we will have to acknowledge our interconnectedness with other beings. In doing so, ecohorror risks reinforcing those fears and the categories they are built upon, but ecohorror also asks us to reconsider some of those fears and to imagine what might happen if we were not to insist so vehemently upon such divisions. ${ }^{16}$

It is the speculative potential of the fantastic which both reveals the social anxieties associated with the consequences of the Anthropocene and makes it possible to conceive alternative scenarios of "getting things in order" (e.g. with respect to

15 E. Thacker, In the Dust of This Planet: Horror of Philosophy, vol. 1, Zero Books, Winchester-Washington 2011, p. 1.

16 C. Tidwell, Ecohorror [in:] R. Braidotti, M. Hlavajova (eds.), Posthuman Glossary, Bloomsbury, London-Oxford-New York-New Delhi-Sydney 2018, p. 117. 
speciesism ${ }^{17}$ ) on Earth, not necessarily in accordance with the notional patterns we have grown accustomed to and take for granted. I believe that science fiction harbours greater potential in that respect than horror, as the latter is by default expected to inspire fear, while the rift in reality caused by a violent (most often irrational) event is unlikely to lead to a happy ending. In contrast, within the fantastic, envisioning alternative realities or a reality organized anew, embracing various forms of existence, social order or - more broadly - interweaving human and non-human agencies fosters the notion that the order in which we live and the principles on which it rests are neither the only viable nor the best. As I do not wish to be misconstrued, I should stress that it is not my intention to prove that science fiction is superior to horror as a genre of the fantastic, but to demonstrate that the challenges faced in the era of the Anthropocene or, as Donna Haraway puts it, in the horror of the Anthropocene and Capitalocene, ${ }^{18}$ require science fiction to be engaged in the discussion rather than any macabre tales. For those reasons, the apocalyptic facet of science fiction does not really deliver as ecofiction that is committed to change. Its bleak, pessimistic overtones make it politically weak, incapable of becoming involved in the process of transformation that could lead to ecologically fairer future. In this respect, I share the view of the author of Science Fiction and the Ecological Conscience that the challenges of the contemporary world with regard to ecological future require science fiction which promotes green revolution, though not through fear but by virtue of profound understanding of our relationships with nature. The marriage of science fiction, philosophy and social movements to raise ecological awareness has greater political potential than apocalyptic scenarios. ${ }^{19}$ Catastrophic thinking nurtures visions of inevitable doom, whereas speculative thinking gravitates towards a different arrangement of relationships between human and non-human animals, diverse ecosystems and human - non-human agencies. Perhaps what needs to be done in the first place is to realize that having long produced tools, processes, and mechanisms to appropriate, explore and subjugate nature, humans make the horror of the Anthropocene more and more realistic with each generation, ${ }^{20}$ only to conclude later that a change of the

17 P. Singer, Animal Liberation: A New Ethics for Our Treatment of Animals, New York Review/Random House, New York, 1975. In a commentary to Singer's new ethics, Ija Lazari-Pawłowska writes: "According to the author, emphasizing dignity of each human individual becomes momentously significant when we wish to defend some category of persons against the harm they have been inflicted, against racism, enslavement, debasement, exploitation, against any breach of human rights. However, it should not serve humans to elevate their own species in a way leading to speciesism." I. Lazari-Pawłowska, Kręgi ludzkiej wspólnoty. Egoizm gatunkowy [in:] Z. Kaleta (ed.), Etyka w teorii i praktyce. Antologia tekstów, Wydawnictwo Uniwersytetu Wrocławskiego, Wrocław 2001, p. 276.

18 Besides 'the Anthropocene', a term in wide use today, Haraway also takes advantage of the notion of 'the Capitalocene', to underline the links between the market, the mechanisms of capitalism and human actions which prove destructive to Earth's ecosystems. D.J. Haraway, Staying with the Trouble: Making Kin in the Chthulucene, Duke University Press, Durham-London 2016, p. 3.

19 E. Otto, Science Fiction ..., op. cit., p. 22.

20 While it is universally assumed in the scientific community that the Anthropocene is characterized by a substantial human impact on the ecosystems and geology of the Earth, there is no consensus 
state of affairs requires not only novel scientific and technological apparatus, but also a distinct sensibility and aesthetic.

Amitav Ghosh, Bengali writer and cultural critic, drew attention to those issues in The Great Derangement: Climate Change and the Unthinkable. In three chapters dedicated respectively to literature, history and politics, the author describes those insane modes of organizing social-political-economic realities which ushered humans into the Anthropocene. According to Ghosh, climate change is the aftermath of systemic "derangement" of that framework, which forces us to be wardens of our own prisons, guardians of an empty future. With ecological concern absent, that future is blackmailed by the whims of the market, the imperative of economic growth and the coercion to consume. Instead of a critical analysis of those processes and taking action for the well-being of all beings, the planet witnesses a pageant of multiple injustices.

Interestingly enough, Ghosh delves into the Anthropocene beginning with literature, which he justifies by stating that climate change is not merely a political and economic problem but a cultural issue as well, stemming from the crisis of imagination. The author points out the limitations of the realist novel, stating that it celebrates individualism, individuals focused inwards, interpersonal and social relationships which are in a sense isolated from other, multilateral relations with non-human beings. Ghosh juxtaposes the established forms of narration about the world and the place of the human in it with the dynamic industrial development, exploitation of nature, and pollution:

I have come to recognize that the challenges that the challenges that climate change poses for the contemporary writer, although specific in some respects, are also products of something broader and older; that they derive ultimately from the grid of literary forms and conventions that came to shape the narrative imagination in precisely that period when the accumulation of carbon in the atmosphere was rewritings the destiny of the earth. ${ }^{21}$

Furthermore, the author notes a temporal concurrence between intensifying climate change in the modern era and the popularity of realistic prose:

(...) it was in exactly the period in which human activity was changing the earth's atmosphere that the literary imagination became radically centered on the human. Inasmuch as the nonhuman was written about at all, it was not within the mansion of serious fiction but rather in the outhouses to which science fiction and fantasy had been banished. ${ }^{22}$

as to the periodization of the process. This is because the process may be approached in terms of the so-called long duration and short duration, which spans several past generations and industrial revolutions. On the successive phases of environmental and geological changes due to human activity see: S.L. Lewis, M.A. Maslin, The Human Planet: How We Created the Anthropocene, Penguin Random House UK, London 2018.

21 A. Ghosh, The Great Derangement..., op. cit., p. 7.

22 Ibidem, p. 66. 
At the time when realistic prose concentrated on the complex human experience (in the individual and collective dimension), it was presumed that the climate is stable and unchangeable while the resources are limitless. Ghosh maintains that since modern novel covers narrow scopes of time and space - rarely going beyond the span of a single life or several generations - it does not take climate change into account and thus does not allow the reader to "acquire" a sensitivity to the environmental change in progress, to see it as a crucial factor affecting the condition of bodies, minds, emotions, and relationships between the human and the non-human. As a pro-ecological writer and critic, Ghosh believes that it is not the realistic prose but science fiction which has the potential to depict threats as well as advance alternative scenarios of a future world which is friendly to human - non-human agencies, which is why he advocates a turn towards science fiction and fantasy, to develop new, hybrid literary forms and language capable of describing the problems of the Anthropocene; in consequence, "the act of reading itself will change once again, as it has many times before." ${ }^{23}$ To Ghosh, the fantastic carries much of what it takes to change the way one thinks about the world and the relationships between various beings, underlines the value of hybrid forms of description and exemplifications of research problems while simultaneously - as many other posthumanists - recognizes the necessity for a change of language, so as to be able to name the phenomena which remained unnoticed in previous ages.

Donna J. Haraway expressed a similar view already in the 1980s, in her Manifesto for Cyborgs. In the text, some of the vital points of argumentation and rhetoric strategy included departure from depiction or representation in favour of simulation, and distancing oneself from the bourgeois novel and realism whilst affirming science fiction instead. In Haraway's opinion, the potential of sci-fi lies chiefly in the ability to simulate alternative orders and experiment with novel modalities of our being in the world. The research, postulating the construction of a feminist-hybrid identity in posthumanist perspective, recalls the following texts: Loving in the War Years by the Latin writer Cherríe L. Moraga, The Ship Who Sang by Anne McCaffrey, Tales of Neveryon by Samuel R. Delany, works by Alice Bradley Sheldon, writing under the male pseudonym James Tiptree, jr., and prose writer Octavia Butler. The researcher's conviction that the fantastic plays a crucial role in transcending existing orders and developing alternative scenarios of conceiving the world and ourselves - as well as inspiring action for change - is also expressed in Haraway's most recent monograph, Staying with the Trouble: Making Kin in the Chthulucene (2016), in which she discusses human responsibility for the fate of the world in the age of the Anthropocene/ Capitalocene. Haraway states explicitly that "science fact and speculative fabulation need each other." ${ }^{24}$ Describing her method as SF, she explains that it denotes the mutually conditioning categories of science fiction, speculative feminism, science fantasy,

23 Ibidem, p. 84.

24 D.J. Haraway, Staying with the Trouble..., op. cit., p. 3. 
speculative fabulation, science fact, string figures..$^{25}$ As Haraway argues, interlacing those categories means a fluctuation between building and destroying models as certain themes and useless tropes are rejected, between risking failure and opening to the chance of discovering something constructive (perhaps even beautiful) which has not been noticed and expressed hitherto. Thus construed, SF makes it possible to present vital issues of the contemporary world, analyze specific and multiple relationships as they change, examine the emerging nodes of inclusion, switching or rejection (at a former site of attachment, e.g. through tradition). The interweaving of those categories aims to simulate and stimulate attitudes, behaviours, actions, and bonds that constitute an alternative to anthropocentrism and the Anthropocene, so that the ethical perspective and solicitude encompasses both humans and non-humans. Therefore Haraway exchanges the notion of familiality for kinship, which highlights the multiplicity of lifeforms and the relationships and bonds that link them; the notion of origin and genesis is extended to symbiogenesis, while the negatively marked Anthropocene is replaced with the Chtulucene, to denote potentiality, fluidity, or transitionality of certain lifeforms into others (living-with, dying-with).

\section{Managing imagination the posthuman way}

The aforementioned Haraway is not the only researcher to employ "thinking with the fantastic" as she elaborates the concepts of the posthuman. Thus far, "thinking with the fantastic" was chiefly associated with the concepts of transhumanism ${ }^{26}$ and anthropology of cyborgs,${ }^{27}$ where the emphasis is put on human relations with highly advanced technology as opposed to conceiving the human as an actor/actant (and Latour's ANT) of extensive, continually transforming ecosystems. Nevertheless, I believe that in recent years the stress has shifted from transhumanist visions of improving the human through science and technology (symbolized by $\mathrm{H}+$ / Human Plus) towards a correlative, community-based thinking which encompasses both hu-

25 Ibidem, p. 10.

26 Sherryl Vint argues that science fiction plays quite an important role in the narratives of many researchers subscribing to transhumanism, as well as in the strategies of AI companies. For instance, numerous sci-fi works were included in the must-read lists of the extropianists, along with the descriptions of anticipated technologies which in themselves differed little from science fiction narratives. Organizations such as the 2045 Initiative, Humanity+, Singularity University, Extropy Institute, or Future of Humanity Institute function based on models of future deriving from science fiction. Articles published in MIT Press journals such as Arc Magazine, New Scientist, or Twelve Tomorrows show increasing interest of the people developing new technologies in sci-fi. Science fiction is even argued to be a kind of consciousness through which transhumanists shape and test reality. S. Vint, Science Fiction and Posthumanism, "Critical Posthumanism. Genealogy of the Posthuman", 24.05.2014, https://criticalposthumanism.net/science-fiction/ (accessed: 12.02.2021).

27 On the involvement of science fiction in cyborg anthropology studies see: C.H. Gray et al. (eds.), The Cyborg Handbook, Routledge, New York-London 1995; G. Gajewska, Arcy-nie-ludzkie. Przez science fiction do antropologii cyborgów, Wydawnictwo UAM, Poznań 2010. 
man and non-human forms of life. The conceptions within critical posthumanism in particular evince that mode of presenting and affirming human - non-human synergies, immersions, and introjections.

Although the intellectual roots of posthumanism and transhumanism are distinct ${ }^{28}$ and the essential goals of both intellectual currents differ ${ }^{29} \mathrm{I}$ would argue that science fiction is a privileged variety of the fantastic for posthumanism as well. Contemporary (post)humanities are witness to characteristic "immersion" or "indebtedness" in science fiction, as in many critical texts literary and/or cinematic works of science fiction provide an important component of the argument, as a metaphor or intellectual experiment, a figure of new subjectivity and settling-in in a multidimensional and diversified world. ${ }^{30}$ One can discern three major areas in which the fantastic is applied to unfold posthumanist concepts.

First, one seeks to revise the humanistic vision of the human and approach human existence in terms of heterogeneity, multiplicity, immersion, which owes to the fact that the ontological status of the human proves highly problematic in posthumanism. As Rosi Braidotti observes, "[ $\mathrm{t}]$ he human is a normative convention, which does not make it inherently negative, just highly regulatory and hence instrumental to practices of exclusion and discrimination." ${ }^{31}$ Gender, sexual orientation, ethnicity, health, economic status are the principal categories of that normative convention which circumscribes the notion of "human," by virtue of which numerous groups have been excluded over the centuries. By rehabilitating the excluded or marginalized persons and groups, posthumanists contribute to the emergence of such fields as disability studies ${ }^{32}$ and monster studies,${ }^{33}$ in which various monsters, hybrids, polyforms, cyborgs from sci-fi prose and films are often seen as figures of a new posthuman

28 These terms often tend to be confused or erroneously treated as synonymous, which is due - among other things - to their concurrence in time, as both intellectual currents developed their principal theses and postulations in the 1980s, while certain issues and notions are shared (e.g. cyborg as a fictitious and simultaneously real entity, or figure of the "future shock"). However, while transhumanism traces its lineage to the Enlightenment humanistic vision of improving human life, posthumanism derives from other sources: anti-humanism, post-structuralism, deconstructionism, and feminism.

29 In the most general terms, critical posthumanism may be described as post-humanism, post-dualism, post-anthropocentrism. More broadly on the differences between the premises and goals of posthumanism and transhumanism see the following entries: C. Wolfe, Posthumanism; F. Ferrando, Transhumanism/Posthumanism [in:] R. Braidotti, M. Hlavajova (eds.), Posthuman Glossary, op. cit., pp. 356-358, 438-439.

30 It is a phenomenon characteristic of Western culture, because in Poland, for example, research scuch M. Bakko, J. Brach-Czaina, E. Domańska, J. Bednarek, T. Sławek sucessfully conduct posthumanist discussion without referring to sci-fi.

31 R. Braidotti, The Posthuman, Polity Press, Cambridge 2013, p. 26.

32 See: K. Alla (ed.), Disability in Science Fiction: Representations of Technology as Cure, Palgrave Macmillan, New York 2013; see also password: D. Goodley et al., Posthuman Disability and DisHuman Studies [in:] R. Braidotti, M. Hlavajova (eds.), Posthuman Glossary, op. cit., pp. 342-345.

33 On the shared areas of posthumanism and monster studies see: P.K. Nayar, Posthumanism, op. cit., pp. 77-87. 
subjectivity that is inclusive instead of exclusive. As Nikita Mazurov explains, the monster is a continuous and simultaneously changing project of disassembly, defiguration and illegitimate combinations; the monster is concrete and yet relational, it relies on hybrid forms which elude notional formalization, it functions through contestation and certain troublesomeness - shifting, adapting, and dissolving in other forms/bodies. The monster undermines the essentialist, Vitruvian concept of the (hu)man: inevitably a white, heterosexual, healthy, able-bodied male, though it is not a "a simplistic negation of the human, but a polymorphous, monstrous aberration of the unitary, humanistic and anthropocentric subject form in its entirety." ${ }^{34}$ The affirmative attitude of posthumanism towards monstrosity stems from transcending the humanistic vision, also because the human is perceived as a being who takes part in evolutionary transformation at various levels, in various ecosystems, vital processes, or genetic material inherited from animal and vegetal ancestors. It is the departure from the humanistic and anthropocentric vision of subjectivity that draws the attention of posthumanists to the monstrous protagonists in science fiction.

Secondly, the aim is to show humans in a nexus of manifold relationships with non-human entities: animals, plants, bacteria, things, and objects. The impulse came from Donna J. Haraway in the monograph entitled The Companies Species Manifesto: Dogs, People, and Significant Otherness, in which she wrote about trans-species relations and taking care to ensure happiness of humans as well as animals (in the text, Haraway focused on the happiness of canine companions to humans); in another books (When Species Meet), the same author spoke of the exceedingly complex relations between people and test animals which work for us in laboratories. As an integral element of the posthuman discourse, animal studies "[show] connections, networks and linkages across life evolve together, embedded within relational structures. ${ }^{35}$ At the same time, they deconstruct the anthropocentric vision of the animal as a being subordinate to the human, and demonstrate that the animal is not the other/ alien, but also that humans as a species are animals, or human animals. Since science fiction is replete with humanimals, plantimals, hybrids and monsters, it offers splendid scope for intellectual experimentation concerning possible and fictitious paths of evolution, as well as denounces value recognition and attribution based on anthropocentric criteria. Pramod K. Nayar aptly notes that "[s]ci-fi asks: what does it mean to be 'truly' human, or 'merely' machine or animal?"36, which is why it enjoys interest among the posthumanists. On the one hand, there are the relations linking humans with the flora and fauna, as well as the animal and vegetal aspect of the human that took its shape in the course of evolution; on the other hand, the matter concerns our relationships with highly developed technology and potential human self-evolution. Nayar further observes:

34 N. Mazurov, Monster/The Unhuman [in:] R. Braidotti, M. Hlavajova (eds.), Posthuman Glossary, op. cit., p. 262.

35 P.K. Nayar, Posthumanism, op. cit., p. 81.

36 Ibidem, p. 93. 


\section{Grażyna Gajewska}

Even when fiction does not explicitly detail contemporary science, it does explore the nature of the human in the age of advanced biotechnology, genetic engineering and computers. From much of the sci-fi, the dystopian novels and other popular expressions, we understand that a new cultural history of the human needs to deal with the question: what forms of the human are now extant and existent? Sci-fi also calls upon us to speculate on the future course of human evolution: what will the human be like tomorrow? What comes after (post-) the human? ${ }^{37}$

These issues are well within the horizon of the posthumanist deliberation, in which it is presumed that technology is not so much a prosthesis or extension of the human condition but its integral component. Hence, directing their attention to the ways in which machines, human, biological bodies and other lifeforms mutually coexist or coevolve, the posthumanists critically analyze those works of science fiction in which such relationships are articulated.

Third, the posthumanist turn towards the fantastic also involves the strategies to mitigate the aftermath of several centuries of adverse environmental impact, and attempts to formulate an ethics of concern for the world all beings share. Popular culture offers plenty of literary and filmic depictions of dystopian future where lack of water, exhaustion of fossil fuels and extinction of numerous plant and animal species (resulting in food shortage) leads to a dramatic environmental change and collapse of social life. Here, posthumanism highlights ecohorror, meaning a subgenre of literary-film horror which reveals our disquiet with the state of the environment and fear of the "vengeance of nature" on humans for the abuse it has suffered, as well as provides a metaphor for the actual effects of the Anthropocene. A common denomination for those two interpretations of the term "ecohorror" may be found in the conciliatory definition advanced by Stephen Rust and Carter Soles in the article Living in Fear, Living in Dread, Pretty Soon We'll All Be Dead. In the opinion of the authors, ecohorror comprises both works which deliver fictitious yet terrifying scenarios of the future, as well as critical tropes and studies geared towards analysis of the ecological crises and focusing on the manifold relationships between human and non-human animals and other actors/actants which inhabit the Earth. ${ }^{38}$ This perspective found approval with posthumanism, because ecohorror understood in this fashion expands the range of works classified as horror in film and literature to include the ecological aspect, demonstrating at the same time that ecohorror is an integral element in the proecological academic discourse. ${ }^{39}$

This viewpoint has a certain drawback as it concentrates on the negative aspects of relations between humans and non-human others and the environment. Consequently it hampers more speculative and creative essays in proecological thinking and describing the world. For these reasons, I am more in favour of Haraway's SF perspective, which entails intellectual and actual inquiry into the multiple connections

37 Ibidem, p. 3.

38 S. Rust, S. Carter, Ecohorror Special Cluster: 'Living in Fear, Living in Dread, Pretty Soon We'll All Be Dead', 'Interdisciplinary Studies in Literature and Environment”, 21.03.2014, pp. 509-512.

39

C. Tidwell, Ecohorror, op. cit., pp. 115-116. 
between various lifeforms in order to foster multispecies justice. Science fiction plays a crucial role in that respect, insofar as it becomes an intellectual testing ground which enables one to experiment with the existent, conventional notions of that justice, and to transcend the modes of describing (inter)species differences, similarities and dependencies which have become established in the philosophical tradition and social life. I am also much inclined to agree with Ghosh that science fiction and fantasy have a great role to play in transforming our sensibility and language to make it capable of portraying the relationships and links between human and non-human ecosystems without reverting continuously to the anthropocentric mindset or descending into the bleak scenarios of ecohorror. We need such an aesthetics and narration which would be capable of leading us out of anthropocentrism and the Anthropocene into the Chthulucene.

Those three areas in which the posthuman is coupled with the fantastic are apparently separate from one another. However, in order to "think" a different world, the non-anthropocentric world of the Chthulucene: through the convolution of relationships, their transitions, synergies, introjections of various forms of life on Earth, in the entire evolutionary complexity, as well as in the disruption and temporariness of existence, one should also revise the notions of the human as an element of those processes. "We are not posthuman; we are compost. We are not homo; we are humus. We are terran; we are earthlings; we are many; we are indeterminate", Haraway observes. ${ }^{40}$ Due to the peculiar nature of the genre, the fantastic can play a vital role in the transformation, insofar as it provokes the authors and the readers or viewers to delve into various scenarios of the revision; insofar as it conveys diverse spectacles of life passing into death and into life; insofar as it involves human and non-human actors/actants; insofar as it experiments, poses question, tries to show and tell the Chthulucene; directs the imagination, the reason, the emotions and the language towards sympoiesis and an aesthetics and ethics which sensitize us to the fact that being one means becoming with many; as one of the multiple forms of life on Earth we have never been and never are alone, or abided isolated from other beings: we do function entangled in complex, dynamic, and fluctuating systems.

\section{Eco-sci-fi in the age of the COVID-19 pandemic}

Shortly after the outbreak of the COVID-19 pandemic, historian and philosopher of science Justin E.H. Smith published a text entitled It's All Just Beginning, in which he shared his reflections on the human attitudes to animals and, even more broadly, on the human conviction that they have gained complete knowledge of the laws of nature and have mastered or tamed it. Now, proud of how exceptional they are, they

40 D. Haraway, Capitalocene and Chthulucene [in:] R. Braidotti, M. Hlavajova (eds.), Posthuman Glossary, op. cit., p. 79. The concept behind the notion of the 'Chthulucene' is elucidated in detail in the previously cited monograph Staying with the Trouble. 
have noticed with surprise that they are by no means such a splendid and indestructible species as many have believed. Describing human notions of their own uniqueness, Smith draws on the portrayals in science fiction, in which most often...

(...) human beings remain the lords of this planet, while other life forms are at best our wards, and at worst our enemies. In movies featuring aliens, in particular, it is always taken for granted that visitors to earth would naturally see our own species as this planet's true and legitimate representatives. In 2016's Arrival, for example, the gastropod-like space travelers not only express single-minded interest in human beings to the exclusion of plants and microbes (not to mention octopuses), but they even take an interest in international affairs, and goad the Americans into working together with the Chinese and Russians.

This is implausible, to say the least. Even if the extraterrestrials were themselves evolved to find only locomoting megafauna salient, they would probably see our planet as a sort of duumvirate arrangement between human and cattle. But it is just as likely that they would be far more attuned to other kinds of organisms, in particular plants and microorganisms, and that they might even themselves be plantlike or microbe-like. They might control their interstellar vehicles by swarming around in a tank of fluid. If such beings were to come to earth, and to suppose after some reconnoitering that the true representatives of this planet are not only not humans, but not animals at all, it is difficult to come up with an argument as to why they would be mistaken in this conclusion. ${ }^{41}$

On the one hand, drawing on the diagnoses of psychoanalyst Slavoj Žižek, Smith perceives popular culture as an emanation of deeply entrenched but hidden convictions; ${ }^{42}$ on the other, he takes advantage of the speculative potential of science fiction to illustrate his argument, seeking to demonstrate that the dreams of power and reign over the Earth are not only illusory but also unethical.

A week after Smith's article was published, "The New Yorker" featured a text entitled The Coronavirus Is Rewriting Our Imaginations. American sci-fi writer Kim Stanley Robinson wrote that "we've been out of synch with the biosphere, wasting our children's hopes for a normal life, burning our ecological capital as if it were disposable income, wrecking our one and only home in ways that soon will be beyond our descendants' ability to repair." ${ }^{43}$ In a period where in many places around the world the coronavirus pandemic took a cruel toll, forced people into isolation and wrought havoc on the economy, Robinson encouraged readers to speculative thinking:

${ }^{41}$ J.E.H. Smith, It's All Just Beginning, "Examined Life”, 23.03.2020, Web-Only, https://thepointmag. com/examined-life/its-all-just-beginning/?fbclid=IwAR3N1PpT1bZqU27I7JTg8kQbeukekhHuFDtNkNb0Cwsh8iywfaJHBOeEeUk (accessed: 26.03.2020).

42 Žižek advanced a psychoanalytical interpretation of texts and films within popular culture in e.g. S. Žižek, Looking Awry: An Introduction to Jacques Lacan Through Popular Culture, MIT Press, Cambridge 1991, and in the series of recorded lectures entitled The Pervert's Guide to Cinema, dir. S. Fiennes, Austria, The Netherlands, Great Britain, 2006.

43 K.S. Robinson, Coronavirus Is Rewriting Our Imagination, "The New Yorker", 1.05.2020, https:// www.newyorker.com/culture/annals-of-inquiry/the-coronavirus-and-our-future?fbclid=IwAR2S3r7bN2QUnFjlhHQDnEZ0_5bKuVUBymtfdJUSpWbN-M5nmtOzPcV3i2o (accessed: 2.07.2020). 
Imagine what a food scare would do. Imagine a heat wave hot enough to kill anyone not in an airconditioned space, then imagine power failures happening during such a heat wave (...). Image pandemics deadlier than the coronavirus. These events, and others like them, are easier to imagine now than they were back in January, when they were the stuff of dystopian science fiction. $^{44}$

I do not know whether all readers of the article found it easy to imagine the "what if," but certainly this mode of disquisition promotes thinking about life in a broader, future-oriented spectrum than "here and now." It is not that writers and readers of science fiction prose possess an exceptional gift of predicting the future - which they do not - but that...

(...) if you read science fiction, you may be a little less surprised by whatever does happen. Often, science fiction traces the ramifications of a single postulated change; readers co-create, judging the writers' plausibility and ingenuity, interrogating their theories of history. Doing this repeatedly is a kind of training. It can help you feel more oriented in the history we're making now. This radical spread of possibilities, good to bad, which creates such a profound disorientation; this tentative awareness of the emerging next stage [future reality - G.G.] - these are also new feelings in our time. ${ }^{45}$

The new feeling in our time to which Robinson refers is not only fear for the health and life of our loved ones and ourselves in the face of the spreading pandemics, but also a profound concern about the future of the next generations in view of climate change, the waves of migrations of people looking for safe, fertile and unpolluted land, as well as new class divisions resulting limited access to natural and technological resources. Interestingly, Robinson finds that science fiction performs best and most compellingly in terms of creating various scenarios of those events.

\section{Conclusion - breaching the wall of imagination}

The speculative functions of science fiction drew the attention of the French military. On December 4th, 2020, the French Minister of the Armed Forces Florence Parly announced that one of the elements of strategic military innovation planned for 2019$2025^{46}$ is engaging science fiction writers and graphic artists. The aim of the project conceived by the Defence Innovation Agency (Agence de l'innovation de défense AID) is reflection on the war of the future. The ten persons of the so-called Red Team are tasked with "breaching the wall of imagination," i.e. they are expected to venture beyond the traditional modes of predicting conflicts. As Parly explains, the idea is to

44 Ibidem.

45 Ibidem.

46 The innovation agenda is outlined in the report entitled IMAGINER AU-DELÀ. Document d'orientation de l'innovation de défense 2019, https://www.defense.gouv.fr/actualites/articles/document-d-orientation-de-1-innovation-de-defense-doid-2019-les-nouvelles-ambitions-du-ministere-en-matiere-d-innovation (accessed: 10.12.2020). 
imagine how future conflicts may look like and develop potential countermeasures. "Let us dare to think differently, let us believe the impossible, imagine the unimaginable and question what only yesterday seemed unchangeable." ${ }^{\prime 7}$ The range of issues that the writers and graphic artists are expected to explore include conquest of space, social control by means of brain implants and aftermath of the global warming. The project was also presented in a promotional video. ${ }^{48}$ In her speech at the launch of the project, Parly appealed to science fiction authors with these words: "surprise us, push us, cut across out paths and take us out of our comfort zone. Be the reconnaissance force which scouts the directions we have not noticed or refused to see. Your mission is serious, valuable, and challenging."

It is difficult to foresee the outcomes of collaboration between the writers and graphic artists who make up the Red Team and the armed forces, although it is not the first attempt of combining sci-fi with military projects; on the contrary, such undertakings have a long tradition. ${ }^{50}$ Still, the fact that science fiction authors were so openly recruited to help devise new strategies of the French Ministry of the Armed Forces may be another argument supporting the proposition that the fantastic - especially in the shape of speculative science fiction - plays a significant role in managing contemporary imagination. Interestingly enough, the AID recognized that one of the priority issues is global warming, understood as a probable cause of new armed conflicts resulting from the attempts to seize fertile land, access to water, biodiverse environment and mineral resources.

47 Speech by Florence Parly, Minister of the Armed Forces on the launching of the Red Team, at the Digital Forum Innovation Défense, Paris, December 4th, 2020, https://www.defense.gouv.fr/salle-de-presse/discours/discours-de-florence-parly/discours-de-florence-parly-ministre-des-armees-a-l-occasion-du-lancement-de-la-red-team-au-digital-forum-innovation-defense-a-paris-le-4-decembre-2020 (accessed: 10.12.2020).

48 L'initiative Red Team Défense: https://www.youtube.com/watch? $\mathrm{v}=\mathrm{jRfp} 37 \mathrm{FYVNc}$ (accessed: 10.12.2020).

49 Ibidem.

50 In 2013, the media circulated the news that the US military had engaged Max Books to work on a futuristic project. The details were unknown, and the results of the collaboration have not been communicated. Clearly, the AID's project is not the first one, and it may be worthwhile to recall an even earlier military-related concept involving cyborgs to which Parly herself also referred. In 1960, Astronautics published an article by Manfred Clynes and Nathan Kline entitled Drugs, Space and Cybernetics. The scientists, working at the time for the NASA, suggested that introducing highly advanced technology into the human body may result in numerous advantageous transformations. The idea was to create human-mechanical hybrids that would be capable of performing in extreme conditions and surviving the no less extreme conditions of space, considering that "altering man's bodily functions to meet the requirements of extraterrestrial environments would be more logical than providing an earthly environment for him in space." The scientists claimed that creating self-controlled technical-organic systems was possible at the stage of scientific and technological advancement of their day, and suggested to call them "cyborgs." Later on, the figure of the cyborgs found a prominent place in popular culture and connoted both the military provenance (in films such as Terminator or RoboCop), as well as overcoming the vision of human as an exclusively biological and spiritual being. On such ambivalences see: G. Gajewska, Arcy-nie-ludzkie..., op. cit., pp. 21-32. 
While previously "thinking with the fantastic" tended to be associated primarily with transhumanism, AI industry and cyborgization, such an approach is evident today in the context of climate change of simulations of its consequences. Faced with the distressing reports and prognoses concerning global warming, ${ }^{51}$ from which it clearly follows that little time is left to tackle the effects of the Anthropocene (such as global warming), directing one's attention to the various scenarios of the future is by all means justified. Due to the inherent qualities and properties of the genre, science fiction is particularly well suited for the task. Its significant role in delineating possible futures or suggesting alternative modes of organizing reality is emphasized by authors (e.g. already cited Robinson, Ghosh), ecocritical literature experts (e.g. Heise, Sperling, Canavan, Evans, Johns-Putra, Otto), and intellectuals involved in the posthuman (e.g. Haraway, Nayar).

As this text opens with a sentence taken from Robinson's article entitled Coronavirus Is Rewriting Our Imaginations: "Science fiction is the realism our time," I feel it would be legitimate to conclude the paper - which by no means ends the discussion as such - with the words of the French Minister of the Armed Forces, Ms. Parly, from the aforementioned December speech: "Soon, it will not be science fiction anymore" ("Bientôt, ce ne sera plus de la science-fiction").

\section{References}

Alla K. (ed.), Disability in Science Fiction: Representations of Technology as Cure, Palgrave Macmillan, New York 2013.

Braidotti R., The Posthuman, Polity Press, Cambridge 2013.

Braidotti R., Hlavayova M. (eds.), Posthuman Glossary, Bloomsbury, London-Oxford-New York-New Delhi-Sydney 2018.

Canavan G., Robinson K.S. (eds.), Green Planets: Ecology and Science Fictions, Wesleyan University Press, Middletown 2014.

Clark T., The Cambridge Introduction to Literature and the Environment, Cambridge University Press, Cambridge 2011.

Derrida J., The Animal That Therefore I Am, ed. M.L. Mallet, transl. D. Wills, Fordham University Press, New York 2008.

Evans R., Fantastic Futures? Cli-fi, Climate Justice, and Queer Futurity, "Resilience: A Journal of the Environmental Humanities" 2017, vol. 4, no. 2-3, pp. 94-110.

Evans R., Nomenclature, Narrative, and Novum: 'The Anthropocene' and/as Science Fiction, „Science Fiction Studies” 2018, no. 45, pp. 484-499.

Gajewska G., Arcy-nie-ludzkie. Przez science fiction do antropologii cyborgów, Wydawnictwo UAM, Poznań 2010.

Garrard G., Ecocriticism, Routledge, New York 2012.

51 On this issue see e.g. reports and documents of the European Union: Energy, Climate change, Environment: https://ec.europa.eu/clima (accessed: 20.02.2021). 
Garrard G. (ed.), The Oxford Handbook of Ecocriticism, Oxford University Press, New York 2014.

Ghosh A., The Great Derangement: Climate Change and the Unthinkable, University of Chicago Press, Chicago-London 2016.

Glotfelty C., Fromm H. (eds.), The Ecocriticism Reader. Landmarks in Literary Ecology, University of the Georgia Press, Athens-London 1996.

Gray C.H. et al. (eds.), The Cyborg Handbook, Routledge, New York-London 1995.

Haraway D., Manifesto for Cyborgs: Science, Technology, and Socialist Feminism in the 1980s, "Socialist Review" 1985, no. 80, pp. 65-108.

Haraway D., Staying with the Trouble: Making Kin in the Chthulucene, Duke University Press, Durham-London 2016.

Haraway D., The Companion Species Manifesto: Dogs, People, and Significant Otherness, Prickly Paradigm Press, Chicago 2003.

Johns-Putra A. (ed.), Climate and Literature, Cambridge University Press, Cambridge, Cambridge-New York-Melbourne-New Delhi 2019.

Lazari-Pawłowska I., Kręgi ludzkiej wspólnoty. Egoizm gatunkowy [in:] Z. Kaleta (ed.), Etyka w teorii i praktyce. Antologia tekstów, Wydawnictwo Uniwersytetu Wrocławskiego, Wrocław 2001.

Lewis S.L., Maslin M.A., The Human Planet: How We Created the Anthropocene, Penguin Random House UK, London 2018.

Nayar P.K., Posthumanism, Polity Press, Cambridge 2014.

Otto E., Science Fiction and the Ecological Conscience, University of Florida, 2006. Doctoral dissertation published online: http://etd.fcla.edu/UF/UFE0013481/otto_e.pdf (accessed: 2.03.2021).

Otto E.C., Green Speculations: Science Fiction and Transformative Environmentalism, The Ohio State University Press, Columbus 2012.

Parly F., The Digital Forum Innovation Défense, December 4th, 2020, Paris, https://www. defense.gouv.fr/salle-de-presse/discours/discours-de-florence-parly/discours-de-florenceparly-ministre-des-armees-a-1-occasion-du-lancement-de-la-red-team-au-digital-foruminnovation-defense-a-paris-le-4-decembre-2020 (accessed: 10.12.2020).

Robinson K.S., Coronavirus is Rewriting Our Imagination, “The New Yorker", 1.05.2020, https://www.newyorker.com/culture/annals-of-inquiry/the-coronavirus-and-our-future?fbclid=IwAR2S3r7bN2QUnFjlhHQDnEZ0_5bKuVUBymtfdJUSpWbN-M5nmtOzPcV3i2o (accessed: 2.07.2020).

Rust S., Soles C., Ecohorror Special Cluster: 'Living in Fear, Living in Dread, Pretty Soon We'll All Be Dead', "Interdisciplinary Studies in Literature and Environment" 2014, no. $21 / 3$.

Singer P., Animal Liberation: A New Ethics for our Treatment of Animals, New York Review/ Random House, New York 1975.

Smith J.E.H., It's All Just Beginning, "Examined Life”, 23.03.2020, Web-Only, https://thepointmag.com/examined-life/its-all-just-beginning/?fbclid=IwAR3N1PpT1bZqU27I7JTg8kQbeukekhHuFDtNkNb0Cwsh8iywfaJHBOeEeUk (accessed: 26.03.2020).

Sperling A., Climate Fictions, "Paradoxa: Studies in World Literary Genres" 2019-2020, no. 31 .

Sperling A., Queer Ingestions: Weird and Vegetative Bodies in Jeff VanderMeer's Fiction [in:] K.E. Bishop, D. Higgins, J. Määtä (eds.), Plants in Science Fiction: Speculative Vegetation, University of Wales Press, Cardiff 2020. 
Sperling A., Radiating Exposures [in:] C. Holzhey, A. Wedemeyer (eds.), Weathering: Ecologies of Exposure, ICI Berlin Press, Berlin 2020, pp. 41-62.

Sperling A., Second Skins: A Body Ecology of Sickness in 'The Southern Reach Trilogy', "Paradoxa: Studies in World Literary Genres" 2016, no. 28, pp. 231-255.

Thacker E., In the Dust of This Planet: Horror of Philosophy, vol. 1, Zero Books, Winchester-Washington 2011.

Vint S., Science Fiction and Posthumanism, "Critical Posthumanism. Genealogy of the Posthuman", 24.05.2014, https://criticalposthumanism.net/science-fiction/ (accessed: 12.02.2021).

Žižek S., Looking Awry: An Introduction to Jacques Lacan Through Popular Culture, MIT Press, Cambridge 1991. 